\title{
Konsep Perencanaan Keperawatan
}

\section{Queen Agave (Queenasiregar@gmail.com)}

\section{Latar Belakang}

Proses keperawatan adalah aktivitas yang mempunyai maksud yaitu praktik keperawatan yang dilakukan dengan cara yang sistematik. Selama melaksanakan proses keperawatan, perawat menggunakan dasar pengetahuan yang komprehensif untuk mengkaji status kesehatan klien, membuat penilaian yang bijaksana dan mendiagnosa, mengidentifikasi hasil akhir kesehatan klien dan merencanakan, menerapkan dan mengevaluasi tindakan keperawatan yang tepat guna mencapai hasil akhir tersebut (Dermawan, 2012).

Proses keperawatan adalah salah satu metoda efektif pemecahan masalah yang dilakukan perawat terhadap klien dengan pendekatan metodologi ilmiah. Asuhan keperawatan dapat dipertanggungjawabkan berdasarkan substansi ilmiah yaitu logis, sistimatis, dinamis dan terstruktur (Muhlisin, 2011). Proses keperawatan adalah suatu metode ilmiah yang sistematis dan terorganisir dalam memberikan asuhan keperawatan pada pasien yang berfokus pada respon individu terhadap gangguan kesehatan yang dialami (Manurung, 2011).

Proses keperawatan digunakan untuk membantu perawat melakukan praktik keperawatan secara sistematis dalam memecahkan masalah keperawatan.Dengan menggunakan metode ini, perawat dapat mendemonstrasikan tanggung gugat dan tanggung jawab pada klien, sehingga kualitas praktik keperawatan dapat ditingkatkan. Proses keperawatan memberikan kerangka yang dibutuhkan dalam asuhankeperawatan kepada klien, keluarga dan komunitas, serta merupakan metode yangefisien dalam membuat keputusan klinik, serta pemecahan masalah baik aktualmaupun potensial dalam mempertahankan kesehatan. 


\section{Metode}

Metode ini menggunakan metode kualitatif analisis berlandaskan teori dari buku, jurnal, e-book ataupun sumber informasi lainnya yang memuat informasi dengan Konsep Perencanaan Keperawatan. Dengan metode ini informasi pembahasan mengenai perencanaan keperawatan. perawat dapat memahami dan mempelajari tentang Perencanaan Keperawatan. Pengertian perencanaan keperawatan, langkah-langkah merumuskan rencana keperawatan (prioritas, tujuan, dan kriteria hasil, rumusan rencana tindakan dan rasional (SIKI), implementasi, pengertian implementasi proses Implementasi (SLKI).

\section{Hasil}

Hasil dari metode kasus secara umumu memiliki kepala ruangan dan anggota tim nya tersendiri dan memiliki tanggu jawab yang berbeda beda. Subjek penelitian berupa individu, kelompok, lembaga maupun masyarakat. Hasil dari penelitian metode kasus ini merupakan suatu generalisasi dari pola pola kasus yang tipikal dan individual, kelompok, lembaga dan sebagainya. Hasil dari metode kasus ini akan berjalan dengan baik apabila perawat tersebut melakukan nya dengan baik dan benar. Seorang perawat harus fokus terhadap satu pasien ataupun perawat memberikan asuhan keperawatan secara total terhadap pasien ny sehingga hasil dari metode ini bisa dikatakan berhasil.

\section{Perencanaan}

keperawatan adalah rencana tindakan kepera watan tertulis yang menggambarkan masalah kesehatan pasien, hasil yang akan diharapkan, tindakantindakan keperawatan dan kemajuan pasien secara spesifik (Manurung, 2011). Adapun tujuan proses keperawatan menurut Manurung (2011) adalah Mempraktikkan metode pemecahan masalah dalam praktik keperawatan, menggunakan standar untuk praktik keperawatan, memperoleh metoda yang baku dan sesuai, rational dan sistematis dalam memberikan asuhan keperawatan pada pasien, memperoleh metoda yang dapat digunakan dalam segala situasi. 


\section{Pembahasan}

Diagnosa keperawatan

1). Pengertian diagnosa keperawatan

Diagnosa keperawatan adalah suatu kesimpulan yang dihasilkan dari analisa data (Carpenito, 2009). Diagnosa keperawatan adalah penilaian klinik tentang respon individu keluarga, atau komunitas terhadap masalah kesehatan atau proses kehidupan yang aktual atau potensia. Diagnosa keperawatan memberikan dasar untuk pemilhan intervensi keperawatan untuk mencapai hasil yang merupakan tanggung jawab perawat menurut North American Nursing Diagnosis Association (NANDA) (1990, dalam Allen, 1998).

Diagnosa keperawatan adalah langkah kedua dari proses keperawatan yang menggambarkan penilaian klinis tentang respon individu, keluarga, kelompok maupun masyarakat terhadap permasalahan kesehatan baik aktual maupun potensial. Dimana perawat mempunyai lisensi dan kompetensi untuk mengtasinya ( Sumijatun, 2010 ). Diagnosa keperawatan adalah pernyataan yang jelas, singkat dan pasti tentang masalah pasien yang nyata serta penyebabnya dapat dipecahkan atau diubah melalui tindakan keperawatan menurut Gordon (1982, dalam Dermawan, 2012).
Diagnosa keperawatan adalah suatu pernyataan yang singkat, tegas, dan jelas tentang respon klien terhadap masalah kesehatan/penyakit tertentu yang aktual dan potensial karena ketidaktahuan, ketidakmauan, atau ketidakmampuan pasien/klien mengatasinya sendiri yang membutuhkan tindakan keperawatan untuk mengatasinya ( Ali, 2009 ).

2). Kriteria diagnosa keperawatan

Kriteria antara lain sebagai berikut ( Nursalam, 2015 ) : Status kesehatan dibandingkan dengan standar untuk menentukan kesenjangan, diagnosa keperawatan dihubungkan dengan penyebab kesenjangan dan pemenuhan kebutuhan pasien, diagnosa keperawatan dibuat sesuai dengan wewenang, komponen diagnosa terdiri atas PE/PES

3). Tujuan diagnosa keperawatan Tujuan diagnosa keperawatan untuk mengidentifikasi menurut Wahid \& Suprapto (2012) sebagai berikut: Masalah dimana adanya respon klien terhadap status kesehatan atau penyakit, faktor yang menunjang atau menyebabkan suatu masalah, kemampuan klien untuk mencegah atau menyelesaikan masalah. 
4) Komponen diagnosa keperawatan

Komponen diagnosa keperawatan menurut Dermawan (2012) sebagai berikut:

\section{a.Problem}

Problem adalah gambaran keadaan pasien dimana tindakan keperawatan dapat diberikan dengan tujuan yaitu menjelaskan status kesehatan pasien secara jelas dan sesingkat mungkin. Diagnosis keperawatan disusun dengan menggunakan standart yang telah disepakati, supaya perawat dapat berkomunikasi dengan istilah yang dimengerti secara umum.

\section{b. Etiologi}

Etiologi atau faktor penyebab adalah faktor klinik dan personal yang dapat merubah status kesehatan atau mempengaruhi perkembangan masalah. Merupakan pedoman untuk merumuskan intervensi. Unsur - unsur dalam identifikasi etiologi meliputi unsur PSMM :

(1) Patofisiologi penyakit : semua proses penyakit, akut atau kronis yang dapat menyebabkan atau mendukung masalah.

(2) Situasional : personal dan lingkungan (kurang pengetahuan, isolasi sosial).

(3) Medikasi (berhubungan dengan program perawatan atau pengobatan) : keterbatasan institusi atau rumah sakit, sehingga tidak mampu memberikan perawatan.

c. Sign and symptom

Data subyektif dan obyektif yang ditemukan sebagai komponen pendukung terhadap diagnosa keperawatan. Sign and symptom (tanda dan gejala) adalah ciri, tanda atau gejala yang merupakan informasi yang diperlukan untuk merumuskan diagnosa keperawatan.

5) Langkah - langkah menentukan diagnosa keperawatan

Langkah - langkah menentukan diagnosa keperawatan menurut Setiadi (2012) sebagai berikut:

a) Klasifikasi dan analisis data

Klasifikasi atau memfokuskan data adalah mengelompokan data-data pasien atau keadaan tertentu dimana klien mengalami permasalahan kesehatan atau keperawatan berdasarkan kriteria permasalahannya.

b) Interpretasi data (1) Menentukan kelebihan pasien. Jika pasien memenuhi standar kriteria kesehatan, perawat akan menyimpulkan bahwa pasien memiliki kelebihan dalam hal tertentu dan kelebihan ini dapat digunakan untuk 
membantu menyelesaikan permasalahan pasien.

c) Validasi data Pada tahap ini perawat memvalidasi data yang ada secara akurat yang dilakukan bersama pasien dan keluarga atau masyarakat. Validasi ini dilaksanakan dengan mengajukan pertanyaan yang reflekif kepada pasien atau keluarga tentang kejelasan interpretasi data.

d) Merumuskan diagnosa keperawatan Perumusan diagnosa keperawatan didasarkan pada identifikasi masalah dan kemungkinan penyebab. Selain itu perumusan diagnosa juga sesuai dengan kebutuhan pasien.

6) Tipe diagnosa keperawatan

Tipe diagnosa keperawatan menurut Carpenito (2009) sebagai berikut:

a) Diagnosa keperawatan aktual.

Diagnosa keperawatan aktual adalah diagnosa menjelaskan masalah yang nyata terjadi saat ini. Pada diagnosa keperawatan aktual batasan karakteristiknya adalah tanda dan gejala yang bila terlihat dalam waktu yang sama mewakili diagnosa keperawatan. Batasan karakteristik dibedakan menjadi karakteristik mayor dan minor. Mayor setidaknya satu tanda harus ada untuk validasi diagnosa, minor mendukung bukti tetapi boleh tidak ada.

b) Diagnosa keperawatan risiko.

Diagnosa keperawatan risiko adalah keputusan klinis yang divalidasi oleh faktor risiko. Tidak terdapat tanda dan gejala mayor.

c) Diagnosa keperawatan potensial.

Diagnosa keperawatan potensial adalah diagnosa yang didasarkan atas kondisi sehat klien untuk mencapai tingkat kesehatan yang lebih tinggi.

d) Diagnosa keperawatan kemungkinan. Diagnosa keperawatan kemungkinan adalah pernyataan tentang masalah yang diduga akan terjadi, masih memerlukan data tambahan.

e) Diagnosa keperawatan sindroma

Diagnosa keperawatan sindroma adalah sekelompok atau kumpulan dari beberapa diagnosa keperawatan yang terjadi secara bersamaan yang memiliki penyebab tunggal. 


\section{Penutup}

Pelaksaan proses keperawatan secara umum bertujuan untuk menghasilkan asuhan keperawatan yang berkualitas sehingga berbagai masalah kebutuhan pasien dapat teratasi . proses keperawatan merupakan cara yang sistematis yang dilakukan oleh perawat bersama pasien dalam menentukan kebutuhan asuhan keperawatan dengan melakukan pengkajian , diagnosis, merencanakn tindakan yang akan di lakukan, melaksanakan tindakan serta mengevaluasi hasil asuhan keperawatan yang telah diberikan dengan berfokus pada pasien. 


\section{Daftar Pustaka}

1. Buheli, K. (2012). Faktor yang mempengaruhi kinerja perawat dalam penerapan proses keperawatan di RSUD Toto Kabupaten Bone Bolango. Sainstek, 6(05).

2. PPNI, T. P. S. D. (2019, October). Standar Diagnosis Keperawatan Indonesia: Definisi dan Indikator Diagnostik. EGC.

3. SARI, R. K. Gambaran Diagnosis Keperawatan Menurut SDKI (Standar Diagnosis Keperawatan Indonesia) di Ruang Iccu (Intensive Coronary Care Unit) Rsd Dr. Soebandi Jember.

4. Rahmawati, R. 2019. Proses dan Kinerja Perawat dalam Melakukan Asuhan Keperawatan. Osfyoh.

5. Astar, F., Tamsah, H., \& Kadir, I.(2017). Pengaruh Pelayanan Asuhan Keperawatan Terhadap Kepuasan Pasien Di Puskesmas Takalala Kabupaten Soppeng. Journal Of Management. Vol. 1, No. 2

6. Bara dan Suryati. (2014). Hubungan Motivasi Perawat dengan Pelaksanaan Pendokumentasian Asuhan Keperawatan di Ruang Rawat Inap RSUD Pasar Rebo. Jurnal Health Quality vol. 5 No. 1

7. SYAFRUDIN, M. (2019). PERENCANAAN AKADEMI KEPERAWATAN DI SAMARINDA DENGAN PENERAPAN LAMIN DAYAK DESA PAMPANG. KURVA S JURNAL MAHASISWA, 1(1), 1696-1708.

8. Kurniawan, D. E., Afandi, A. T., Purwandari, R., Rifai, A., Ardiana, A., \& Nur, K. R. M. Proses dan Dokumentasi Keperawatan: Pendekatan Konsep dan Praktik.

9. ARIYANTI, H. R. (2019). PENGEMBANGAN CLINICAL PATHWAY KLIEN CVA INFARK: DIAGNOSIS DAN INTERVENSI KEPERAWATAN BERBASIS SDKI DAN SIKI TERHADAP MUTU PELAYANAN KEPERAWATAN DI RUMAH SAKIT (Doctoral dissertation, Universitas Airlangga).

10. Qonita, I. N., Widowati, I., \& Ns, M. K. (2019). ASUHAN KEPERAWATAN JIWA GANGGUAN KONSEP DIRI: HARGA DIRI RENDAH DAN LATIHAN PENINGKATAN ASPEK POSITIF YANG DIMILIKI PADA PASIEN Sdr. A DAN Tn. H DI RUANG DEWA RUCI RSJD Dr. AMINO GONDOHUTOMO PROVINSI JAWA TENGAH.

11. Butar-Butar, J., \& Simamora, R. H. (2016). Hubungan Mutu Pelayanan Keperawatan dengan Tingkat Kepuasan Pasien Rawat Inap di RSUD Pandan Kabupaten Tapanuli Tengah. Jurnal Ners Indonesia, 6(1), 50-63.

12. Simamora, R. H. (2005). Hubungan Persepsi Perawat Pelaksana Terhadap Penerapan Fungsi Pengorganisasian Yang Dilakukan Oleh Kepala Ruangan Dengan Kinerjanya Diruang Rawat Inap RSUD Koja Jakarta Utara (Doctoral dissertation, Tesis FIK UI, Tidak dipublikasikan). 